\title{
Composite Flap - Serratus Anterior with Rib Component - a Foot Salvage Solution after a Severe Crush Injury
}

\author{
Andrei MARIN', Carmen GIUGLEA ${ }^{1,2}$, Silviu MARINESCU ${ }^{2,3}$, Ruxandra MIHAI ${ }^{3}$
}

\begin{abstract}
Severe work accidents are one of the most frequent causes for physical disability in adults, alongside car accidents and war/gunshot injuries. In this article we present the case of a severe crush injury of the left foot that occurred in a 31 year-old patient who was involved in a work accident. After an unsuccessful tissue coverage using local flaps, the salvage solution was that of a composite free flap, aiming not only to cover, but also to restore stability to the foot. The treatment of choice was the serratus anterior muscle harvested together with osseous component $\left(8^{\text {th }}\right.$ rib). The healing was difficult, due to wound dehiscence with bone exposure over a small area, but the problem was addressed using FGF (fibroblast growth factor) sponges, which enabled granulation and complete wound closure. The outcome of the case was favourable, gait being possible without any deficiency. For the cosmetic and functional reasons, the patient suffered one last surgical procedure to debulk the dorsal aspect of the foot. The final result was more than satisfactory, the patient being totally rehabilitated and socially and professionally reintegrated.
\end{abstract}

Keywords: serratus anterior free flap, crush injury, foot reconstruction, composite flap.

\section{Rezumat}

Accidentele severe de muncă reprezintă una dintre cele mai frecvente cauze de disfuncție fizică în cazul adulților, alături de accidentele auto și leziunile provocate de focurile de armă. În acest articol prezentăm cazul unui pacient în vârstă de 31 de ani, care a suferit un accident de muncă - o leziune severă prin strivire la nivelul piciorului stâng. După o tentativă eșuată de acoperire cu lambouri locale, soluția salvatoare a fost aceea a unui lambou compozit care nu doar să asigure acoperirea cu țesuturi moi viabile, ci să și confere stabilitate piciorului. Astfel s-a optat pentru un lambou liber transferat format din mușchiul dințat anterior recoltat împreună cu componentă osoasă (coasta a 8-a). Vindecarea a fost dificilă, datorită dehiscenței cu expunere osoasă pe o minimă suprafață. Problema a fost abordată prin pansamente cu bureți cu FGF (factor de creștere fibroblastică), care a permis granularea și închiderea completă a plăgii. Rezultatul a fost unul favorabil, mersul fiind posibil fără niciun fel de deficiențe. Din motive cosmetice și funcționale, pacientul a suferit o nouă intervenție chirurgicală de reducere a volumului de pe fața dorsală a piciorului. Rezultatul final a fost mai mult decât satisfăcător, pacientul fiind complet reabilitat și integrat social și profesional.

Cuvinte cheie: lambou dințat anterior, leziune prin strivire, reconstrucție de picior, lambou compozit.

\footnotetext{
1 Department of Plastic Surgery, "Sf. Ioan" Emergency Clinical Hospital, Bucharest Romania

2 "Carol Davila" University of Medicine and Pharmacy, Bucharest, Romania

${ }^{3}$ Department of Plastic Surgery, „Bagdasar Arseni” Emergency Clinical Hospital, Bucharest, Romania
}

Corresponding author:

Andrei MARIN, Department of Plastic Surgery, "Sf. Ioan" Emergency

Clinical Hospital, Bucharest Romania.

E-mail: marin_dpt@yahoo.com 


\section{INTRODUCTION}

Limb salvage surgery is performed in extreme situations. The decision to primarily amputate or to try saving a mangled extremity is difficult to make and for this reason several scores have been developed in order to aid the surgeon in making the right call ${ }^{1,2}$.

High-level energy injuries often imply devascularized soft tissues and bone loss. In lower extremity, injuries classified in Gustilo Anderson type 3 are candidates for limb salvage solutions which involve bone and soft tissue replacement ${ }^{3,4}$.

For the distal third of the lower limb, the serratus anterior muscle is a reliable flap used for covering defects ${ }^{5}$. Its arterial supply consists of 3 different branches - the superior thoracic artery (in the upper part), the lateral thoracic artery, and the thoracodorsal artery (in the lower part), while it's innervation is provided by the long thoracic nerve. It's origin on the $8^{\text {th }}$ and $9^{\text {th }}$ ribs offers the possibility of harvesting this flap together with an osseous component, making it suitable for complex reconstruction procedures.

\section{CASE PRESENTATION}

A 31 year-old patient suffered a work accident in which his left foot got tangled in an industrial grinding machine, resulting in complex defects of the metatarsals IV, V and of the cuboid bone. For this reason, the patient was first admitted in the Department of Orthopedics within „Bagdasar Arseni” Emergency Hospital.

At admission, blood tests were performed, revealing a mild leukocytosis $(13.500 / \mathrm{mL})$, slightly elevated prothrombine time (15.3s) and elevated ALT (106 U/L) but normal levels of electrolytes. EKG and pulmonary $\mathrm{X}$-ray were also normal. Wound swab cultures were harvested routinly on admisson. The patient had no other known comorbidities.

The local examination revealed massive crushing of the dorsum aspect of the left foot, defect of the soft tissue and of the bone in the lateral extremity of the foot (IV and V metatarsal bones, defect of the tarsal bones) and lack of tissue including skin, subcutaneous tissue, extensor and flexor tendons, vascular-nervous pack of the IV and V toes. The IV and V toes were still in place, but they had circulatory modifications and massive foreign residue impregnated in the soft tissue.

Due to the severe vascular suffering and extensive soft tissue defects, the patient was transferred to the Plastic Surgery Department in the same day.

The first surgical intervention consisted of surgical debridement, eschilectomy, excision of the bone structure of the $5^{\text {th }}$ toe and fillet flap for coverage of the lateral aspect of the forefoot; local random advancement flap and skin graft to cover the defects.

The patient received antibiotics, vasodilators, anticoagulants, antalgic and anti-inflammatory medication to increase flap survival chance. However, the poor vascularity determined full flap necrosis by day 10 .

At this point, the patient underwent a second intervention - reconstruction using a composite free flap (serratus anterior with $8^{\text {th }}$ rib). The necrotic tissue on the dorsum of the foot was debrided and the dissection was performed at the level of the ankle to identify the anterior tibial artery. The donor site was prepared and the dissection of the serratus anterior muscle covering the ribs 7-9 was performed. The osteomuscular flap was raised on the thoracodorsal artery and then transferred at the recipient site. Anastomosis of the thoracodorsal artery to the anterior tibial artery, followed by venous anastomosis and osteosynthesis with $\mathrm{K}$ wire were performed. The serratus anterior muscle was then covered by a split thickness skin graft.

The free flap transfer followed a strict protocol, which involved surveillance every hour for the first 6 hours, then every 2 hours for the next 12 hours, then every 4 hours for the next 3 days and then every 6 hours for next days of the first week. The surveillance protocol involved measuring the temperature at the surface of the flap as well as observing the color, the turgor and the capillary flow.

The proximal part of the flap was well vascularized and healed uneventfully, while the distal part of the flap had a minor vascular suffering, which resulted in bone exposure over the distal and lateral aspect of the flap. The small area of exposed bone was treated using FGF (fibroblast growth factor) with collagen sponges. These enabled the formation of granulation tissue and per secundam epithelization.

The result was a good one from a functional perspective, as the patient could walk and climb stairs without difficulty. The X-ray of the foot at 4 months showed good bone integration.

Because the dorsal aspect of the foot was bulky and the patient had trouble finding shoes to fit, he came for a final revision surgery after one year. After the last procedure, the result was both functionally as well as aes- 
thetically improved. A six year follow-up of the patient revealed good scar remodeling, the patient admitting that he returned to work the second year after the injury.

\section{RESULTS AND DISCUSSIONS}

Serratus anterior flap can be the treatment of choice for severe foot injuries, when the defect involves not only bone but also soft tissue ${ }^{5}$. Perrot et al. demonstrated in a 5 year follow-up study on 20 patients that this option is a better solution than that of the fibular free flap when coverage is needed, although the bone quality is better in the fibula than in the rib ${ }^{6}$.

The pedicle length of the serratus anterior - rib flap is suitable for foot reconstruction and the possibility of performing both bone transfer and soft tissue coverage in the same operation is a major advantage of this option ${ }^{7}$.

However, sacrificing the thoracodorsal artery reduces the vascularity to other important muscles such as latissimus dorsi, thus compromising it if needed later for a free transfer; therefore the harvesting the serratus anterior - rib flap on another vascular pedicle should be taken into consideration when possible. Lipa et al described the case of the serratus anterior free flap in which the lateral thoracic artery was the dominant blood supply and the flap could be raised and transferred based on this pedicle ${ }^{8}$. Although this is not the general rule, local anatomy should be considered when harvesting this flap.

Collagen/gelatin sponges impregnated with FGF are known to promote wound healing by initiating mitogenesis and angiogenesis 9 . The collagen/gelatin sponge with FGF acts as an accelerator for the formation of a dermis-like tissue, twice or even 3 times faster than the artificial dermis ${ }^{10}$.

\section{CONCLUSIONS}

The serratus anterior - rib free flap is a versatile solution for forefoot reconstruction after major traumas. The pedicle length of the flap is generous and the vessel diameters are similar, making this myoosseous flap suitable for free transfer in the distal third of the lower limb. Being a composite flap, the serratus anterior - rib free flap provides in one operation both stability and good coverage.

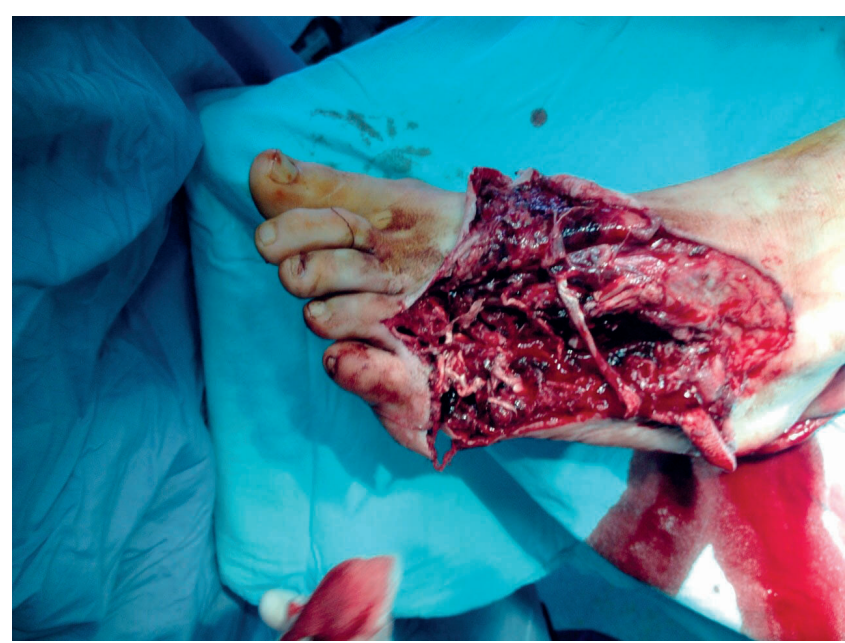

Clinical aspect of the injury
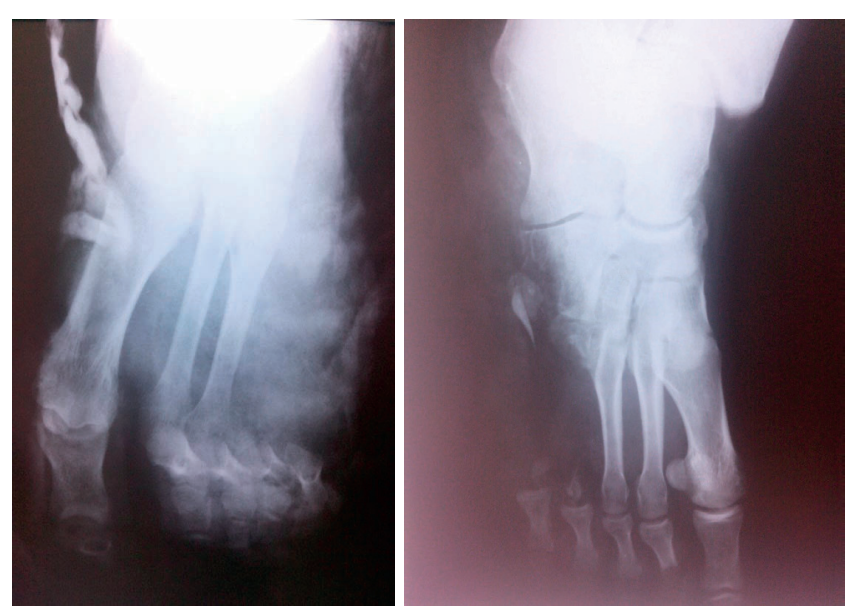

Radiologic aspect of the foot with bone defect

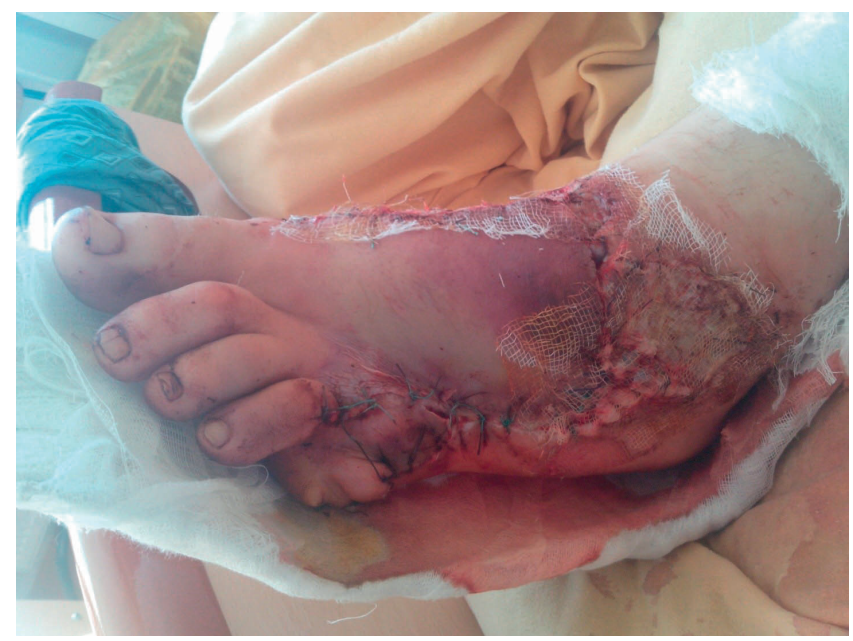

Unsuccesful soft tissue coverage using a random flap 


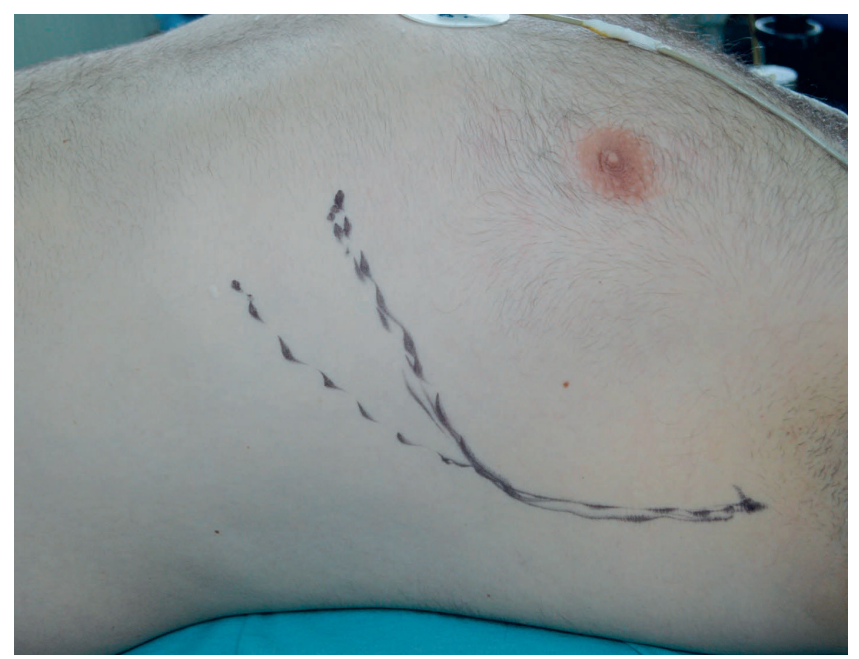

Donor site drawing for composite flap
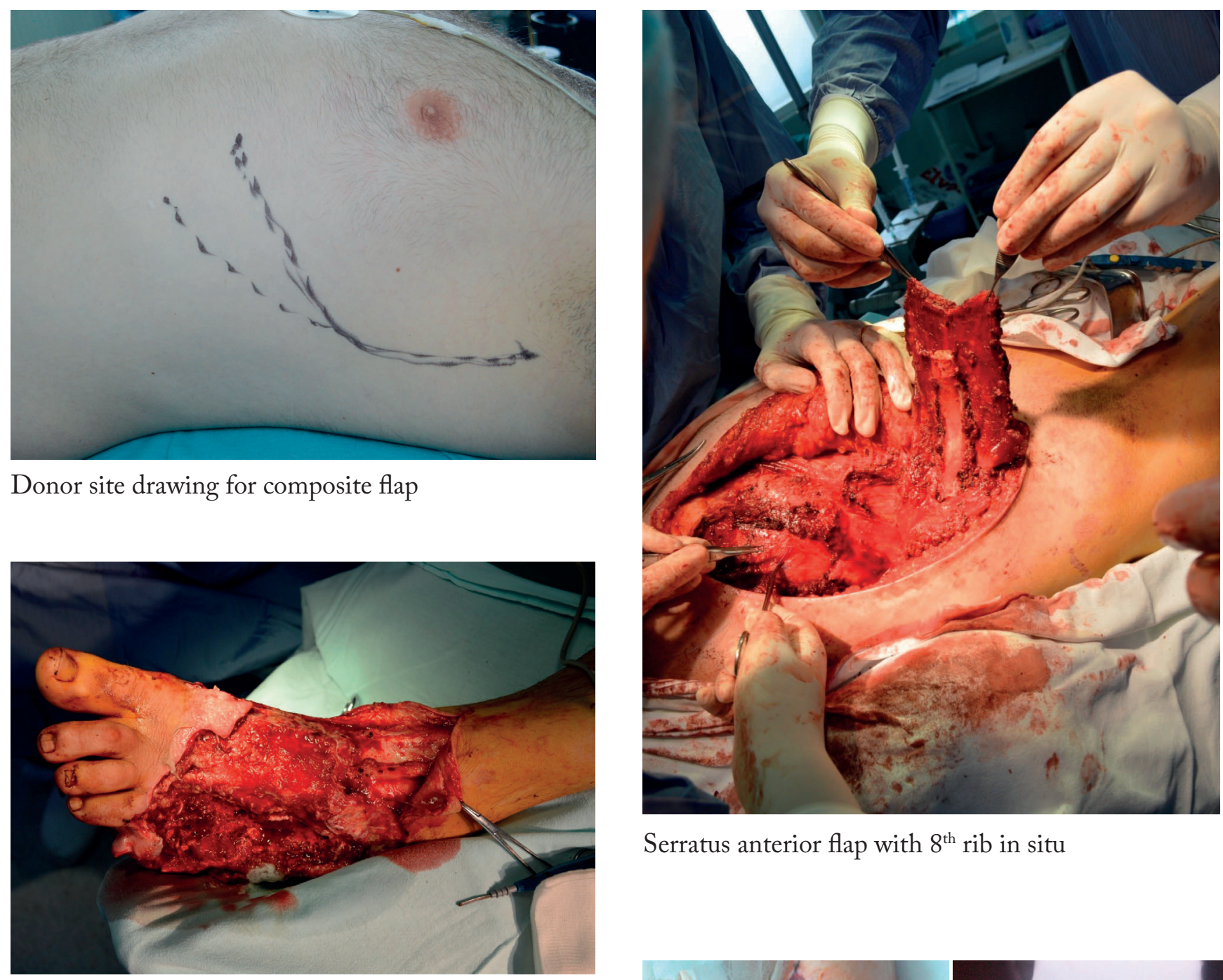

Serratus anterior flap with $8^{\text {th }}$ rib in situ

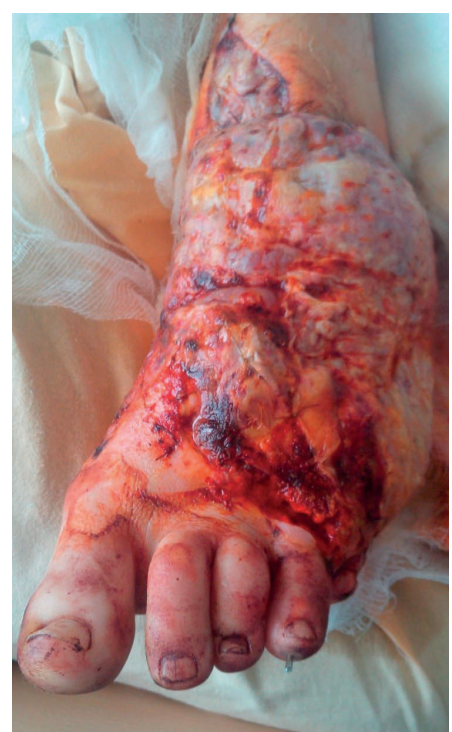

Postoperative aspect at 7 days

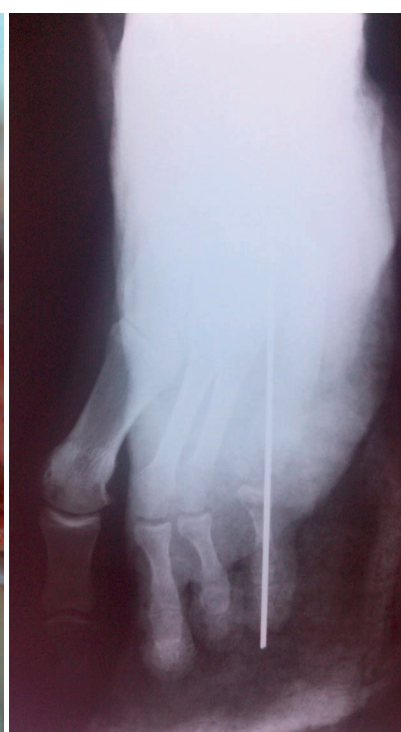

Postoperative radiologic aspect 


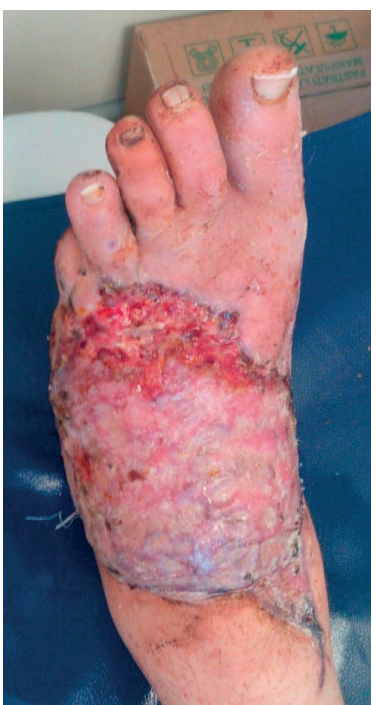

2 months

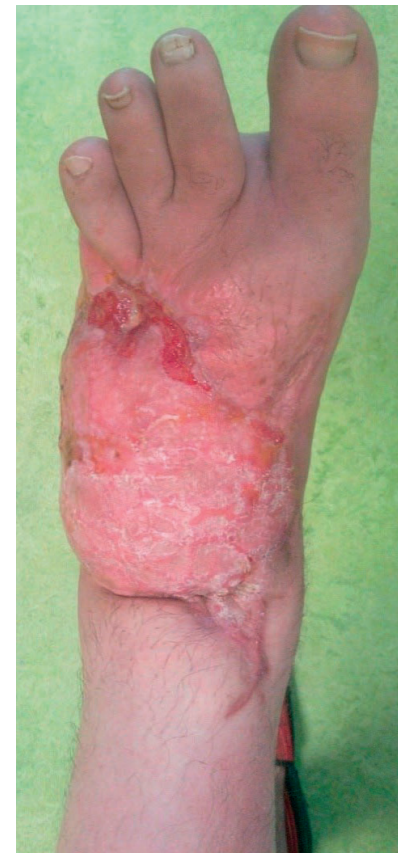

3 months

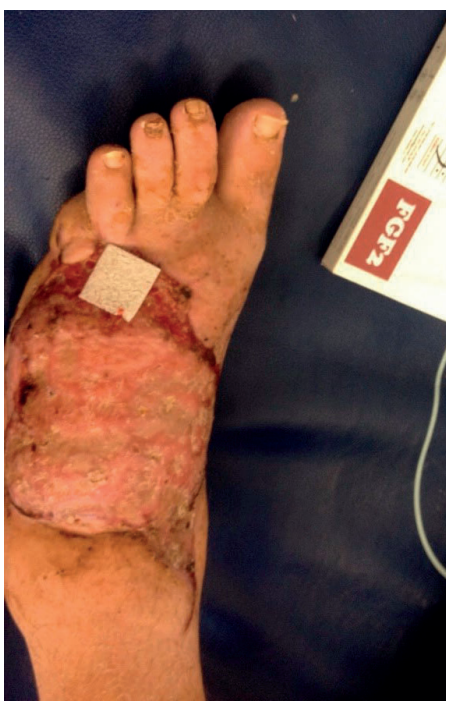

FGF sponge on exposed bone

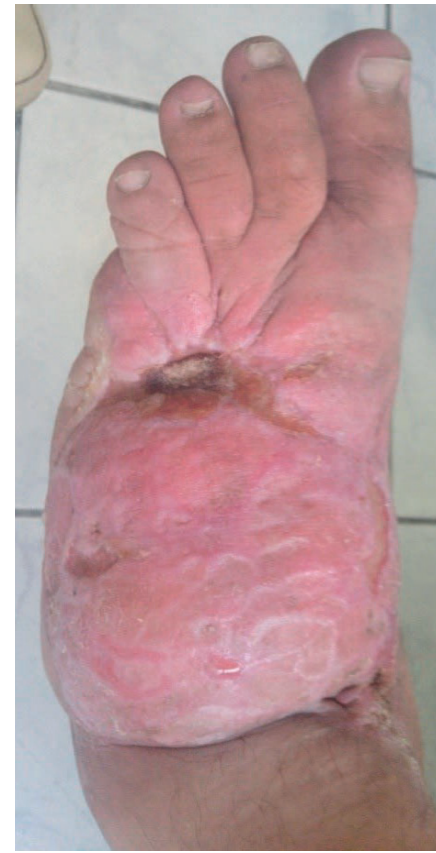

6 months

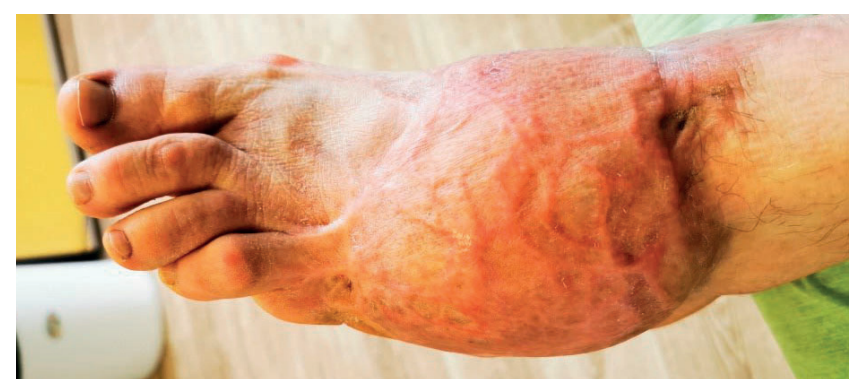

6 years

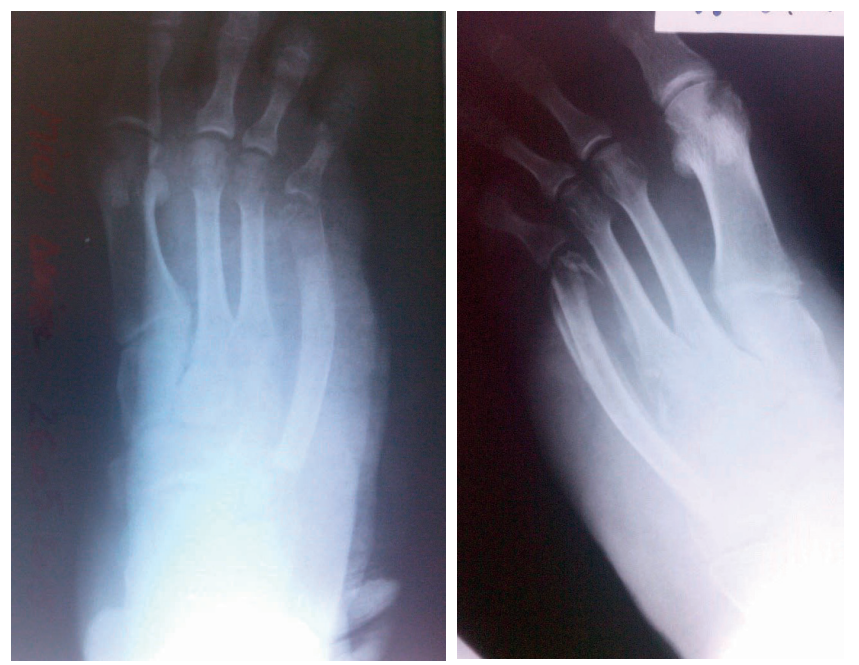

Radiologic exam 4 months from accident

Compliance with ethics requirements: The authors declare no conflict of interest regarding this article. The authors declare that all the procedures and experiments of this study respect the ethical standards in the Helsinki Declaration of 1975, as revised in 2008(5), as well as the national law. Informed consent was obtained from all the patients included in the study. 


\section{References}

1. Schirò GR, Sessa S, Piccioli A, Maccauro G. Primary amputation vs limb salvage in mangled extremity: a systematic review of the current scoring system. BMC Musculoskelet Disord. 2015 Dec 2;16:372. doi: 10.1186/s12891-015-0832-7. PMID: 26796522; PMCID: PMC4722671.

2. Fodor L, Sobec R, Sita-Alb L, Fodor M, Ciuce C. Mangled lower extremity: can we trust the amputation scores? Int J Burns Trauma. 2012;2(1):51-8. Epub 2012 Feb 5. PMID: 22928167; PMCID: PMC3415969.

3. Houdek MT, Wagner ER, Watts CD, Sems SA, Moran SL. Free Composite Serratus Anterior-Latissimus-Rib Flaps for Acute OneStage Reconstruction of Gustilo IIIB Tibia Fractures. Am J Orthop (Belle Mead NJ). 2018 Jun;47(6). doi: 10.12788/ajo.2018.0047. PMID: 29979800.

4. Ricci JA, Abdou SA, Stranix JT, Lee ZH, Anzai L, Thanik VD, Saadeh PB, Levine JP. Reconstruction of Gustilo Type IIIC Injuries of the Lower Extremity. Plast Reconstr Surg. 2019 Oct;144(4):982-987. doi: 10.1097/PRS.0000000000006063. PMID: 31568316.

5. Karir A, Stein MJ, Shiga S, Zhang J. Reconstruction of Lower Extremity Defects Using the Serratus Anterior Free Flap: A Systematic Review and Retrospective Case Series. J Reconstr Microsurg. 2020 Feb;36(2):116-126. doi: 10.1055/s-00391697920. Epub 2019 Sep 25. PMID: 31556091.

6. Perrot $P$, Kitsiou $C$, Yeo $S$, Lescour V, Duteille F. Le lambeau libre composite costomusculaire de serratus anterior dans le traitement des pertes de substance complexes du membre inférieur: à propos de 20 cas avec 5 ans de recul [Reconstruction of lower limb involving free serratus anterior with rib myo-osseous composite flap: 20 patients followed for 5 years]. Ann Chir Plast Esthet. 2016 Aug;61 (4):263-9. French. doi: 10.1016/j.anplas.2015.08.005 Epub 2015 Sep 26. PMID: 26412582.
7. Kitsiou C, Perrot P, Duteille F. La reconstruction des pertes de substance complexes du pied par lambeau libre ostéomusculaire de serratus anterior-côte : à propos de quatre cas [Reconstruction of complex foot defects by serratus anterior-rib osteomuscular free flap: about four cases]. Ann Chir Plast Esthet. 2013 Aug;58(4):3216. French. doi: 10.1016/j.anplas.2012.10.009. Epub 2012 Nov 30. PMID: 23201295

8. Lipa JE, Chang DW. Lateral thoracic artery as a vascular variant in the supply to the free serratus anterior flap. J Reconstr Microsurg. 2001 Aug;17(6):413-5. doi: 10.1055/s-2001-16353. PMID: 11507686.

9. Kakudo N, Morimoto N, Ogawa T, Kusumoto K. Effects of Fibroblast Growth Factor-2 Combined With a Collagen/Gelatin Sponge for Adipogenesis in the Mouse Subcutis. Ann Plast Surg. 2020 Feb;84(2):216-221. doi: 10.1097/SAP.0000000000002046. PMID: 31688113.

10. Kanda N, Morimoto N, Takemoto S, Ayvazyan AA, Kawai K, Sakamoto Y, Taira T, Suzuki S. Efficacy of novel collagen/gelatin scaffold with sustained release of basic fibroblast growth factor for dermis-like tissue regeneration. Ann Plast Surg. 2012 Nov;69(5):569-74. doi: 10.1097/SAP.0b013e318222832f. PMID: 21734552 